\title{
Establishment of a Normal Hematopoietic and Leukemia Stem Cell Hierarchy
}

\author{
M.P. ChaO, J. Seita, AND I.L. Weissman \\ Stanford Institute for Stem Cell Biology and Regenerative Medicine, \\ Stanford University School of Medicine, Stanford, California 94305
}

\begin{abstract}
Many types of adult tissues, especially for high turnover tissues such as the blood and intestinal system, stand on a hierarchical tissue-specific stem cell system. Tissue-specific stem cells concurrently have self-renewal capacity and potential to give rise to all types of mature cells in their tissue. The differentiation process of the tissue-specific stem cell is successive restriction of these capacities. The first progeny of tissue-specific stem cells are multipotent progenitors (MPPs) that lose long-term self-renewal capacity yet have full lineage potential. MPPs in turn give rise to oligopotent progenitors, which then commit into lineage-restricted progenitors. This hierarchical system enables a lifelong supply of matured functional cells that generally have a short life span and a relatively high turnover rate. In this chapter, we review our findings and other key experiments that have led to the establishment of the current cellular stem and progenitor hierarchy in the blood-forming systems of mice and humans for both normal and leukemic hematopoiesis. We also review select signaling pathways intrinsic to normal hematopoietic and leukemic stem cell populations as well our recent findings elucidating the possible origin of the leukemia stem cell.
\end{abstract}

\section{HIERARCHICAL STRUCTURE OF THE MOUSE HEMATOPOIETIC SYSTEM}

The hematopoietic system is one of the most complicated but most investigated systems, which has centered on the identification of the hematopoietic stem cell (HSC). The concept of a tissue-specific stem cell in the blood system was first proposed by Till and McCulloch in 1961 when they found that rare cells in the mouse bone marrow could form myeloerythroid colonies in the spleens of irradiated mice transplants, in which a subset of these cells could self-renew (Till and McCulloch 1961; Becker et al. 1963; Siminovitch et al. 1963; Wu et al. 1968). This finding led to the eventual isolation of mouse HSCs in 1988 by prospective isolation using fluorescence-activated cell sorting (FACS) with combinations of monoclonal antibody cell surface determinants (Spangrude et al. 1988). The Thy $-1{ }^{10}$ Lin-Sca ${ }^{+}$population identified had a frequency of $0.05 \%$ in the mouse adult bone marrow, and limited cell numbers could fully reconstitute the hematopoietic system in lethally irradiated mice long term while giving rise to progeny in all defined myelolymphoid lineages (Spangrude et al. 1988). Since that finding, the mouse functional HSC has been more extensively defined (Fig. 1) (Ikuta and Weissman 1992; Uchida and Weissman 1992; Christensen and Weissman 2001; Kiel et al. 2005). These mouse HSCs when transplanted at the single-cell level give rise to lifelong hematopoiesis, including a steady-state HSC pool between 20,000 and 100,000 that gives rise to more than $10^{9}$ blood cells produced daily (Smith et al. 1991; Osawa et al. 1996; Morrison et al. 1997; Wagers et al. 2002b). Using a combination of cell surface marker expression and functional readout assays, the developmental cellular hierarchy of HSCs was then next achieved (Fig. 1). At the top of the hierarchy sits HSCs that possess lifelong self-renewal capacity. These cells then advance to the MPP phase (Morrison and Weissman 1994;
Christensen and Weissman 2001). Studies reveal that these MPPs are heterogeneous (Osawa et al. 1996; Christensen and Weissman 2001; Kiel et al. 2005) and are in the process of being further characterized (Adolfsson et al. 2005; Forsberg et al. 2006; Arinobu et al. 2007). Further downstream, MPPs give rise to two oligopotent progenitors: (1) the common lymphoid progenitor (CLP) (Kondo et al. 1997) and (2) the common myeloid progenitor (CMP) (Akashi et al. 2000), in which CMPs then give rise to megakaryocyte-erythrocyte progenitors (MEPs) and granulocyte-macrophage progenitors (GMPs). These downstream oligopotent progenitors then give rise to all of the lineage-committed effector cells of the hematopoietic system, with both CMPs and CLPs proposed to give rise to dendritic cells. The current hematopoietic stem cell hierarchy is outlined in Figure 1.

Under normal conditions, lineage-restricted progenitors do not detectably self-renew. They must therefore be derived continually from HSCs, in which the steady-state HSC pool is tightly regulated. Entry into the cell cycle is therefore restricted in the HSC population $(<2 \%$ enter the cell cycle per day, whereas higher percentages of MPP, CLP, and CMP enter the cell cycle each day) (Ogawa 1993; Morrison and Weissman 1994; Kondo et al. 1997; Akashi et al. 2000; D. Bhattacharya et al., unpubl.). This multitiered scheme allows for an enormous amplification in the numbers of terminally differentiated cells and enables precise regulation of homeostasis exemplified by the observation that mature blood cells produce more than 1 million cells per second in adult humans (Ogawa 1993).

\section{HIERARCHICAL STRUCTURE OF THE HUMAN HEMATOPOIETIC SYSTEM}

Taking advantage of similar methods used to identify the mouse HSC hierarchy, the prospective isolation of 


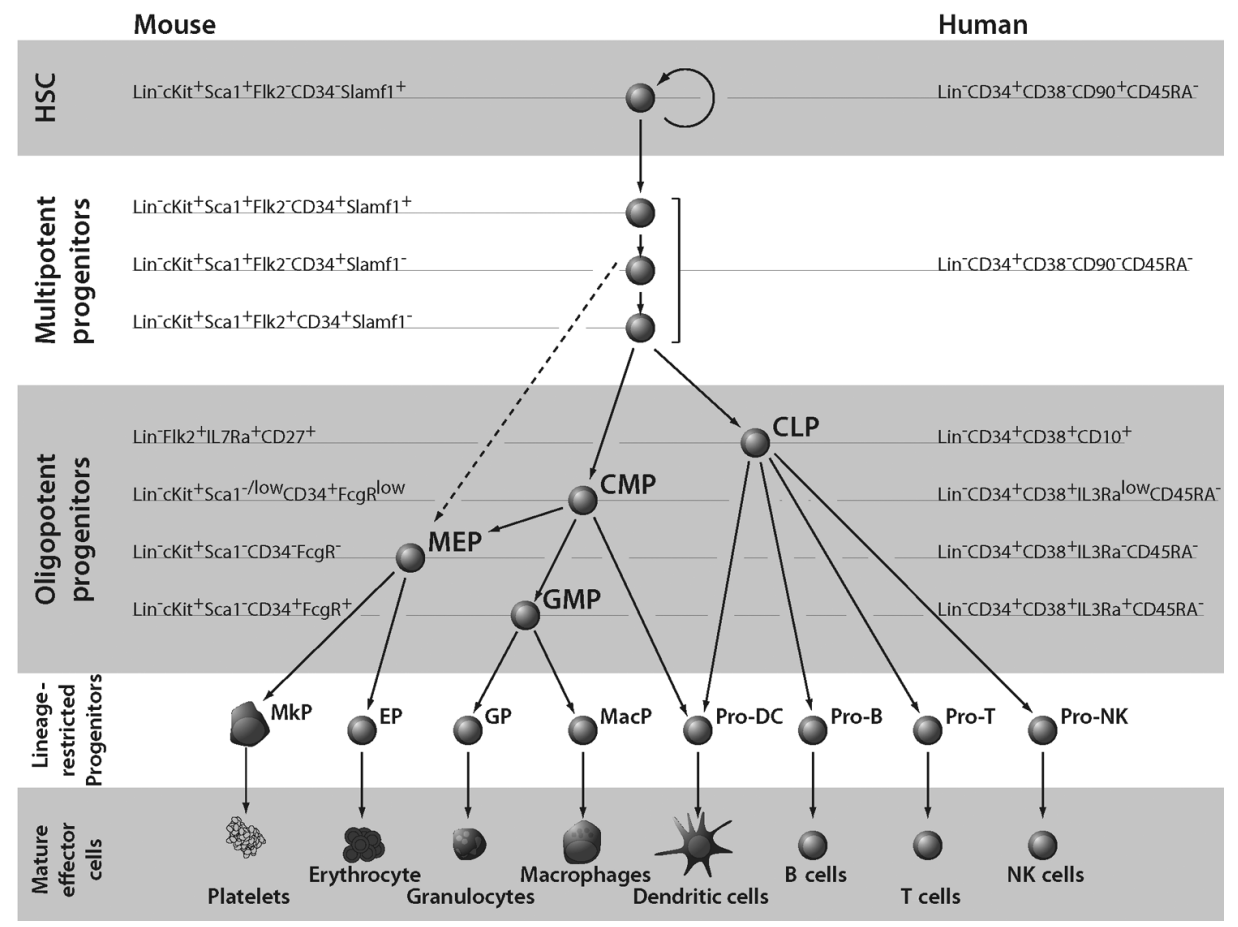

Figure 1. Model of the mouse and human hematopoietic hierarchy. The HSC resides at the top of the hierarchy and is defined as the cell that concurrently possesses both self-renewal capacity and potential to give rise to all hematopoietic cell types (multipotency). Throughout differentiation, an HSC first loses self-renewal capacity, then loses lineage potential step by step, and finally commits to matured functional cells of certain lineages. The cell surface phenotype of each population is shown for the murine and human systems. Intermediate precursors between the first lineage-committed progenitor and finally matured cell and subsets of matured B and T cells are omitted. In the mouse system, heterogeneity of multipotent progenitors by the difference of the cell surface marker phenotype has been revealed, and functional differences of these subsets have been discussed. For example, evidence suggests that some subset of MPPs directly give rise to MEPs without passing through CMPs (dashed arrow). (HSC) Hematopoietic stem cell; (CLP) common lymphoid progenitor; (CMP) common myeloid progenitor; (MEP) megakaryocyte-erythrocyte progenitor; (GMP) granulocyte-macrophage progenitors; (MkP) megakaryocyte progenitor; (EP) erythrocyte progenitor; (GP) granulocyte progenitor; (MacP) macrophage progenitor; (DC) dendritic cell; (NK) natural killer; (Lin) lineage markers.

human HSCs and downstream progenitors has also been achieved. The first positive marker used to identify human HSCs was identified two decades ago as the cell surface antigen CD34. CD34 is expressed in the nonhematopoietic tissues of endothelial cells and is a ligand for L-selectin (CD62L). Of hematopoietic cells in the human fetal liver, cord blood, and bone marrow, 0.5-5\% express CD34 (Civin et al. 1984; Krause et al. 1996) with only CD34 cells possessing in vitro clonogenic potential (Civin et al. 1984; DiGiusto et al. 1994; Krause et al. 1996). Although almost all $\mathrm{CD} 4^{+}$cells show stem cell potential in vitro, the $\mathrm{CD}_{3} 4^{+}$cell population is very heterogeneous. The majority of $\mathrm{CD}^{+} 4^{+}$cells $(90-99 \%)$ coexpress the CD38 antigen. However, only $1-10 \%$ of CD $34^{+}$cells that do not express CD38 and mature lineage markers contain single cells with in vitro bilineage, lymphoid, and myeloid differentiation potential (Baum et al. 1992; Huang and Terstappen 1994; Hao et al. 1998; Miller et al. 1999). Furthermore, $\mathrm{CD} 34^{+} \mathrm{CD} 38^{-}$cells and not $\mathrm{CD} 34^{+} \mathrm{CD} 38^{+}$ cells are highly enriched for LTC-IC (Hao et al. 1996; Petzer et al. 1996) and contain severe combined immunodeficiency disease (SCID) human (hu) repopulating cells (Baum et al. 1992) and nonobase diabetic (NOD)-SCID repopulating cells (Larochelle et al. 1996; Bhatia et al. 1997) in vivo, with read-out in secondary NOD-SCID transplants. Further elucidation of the human HSC phenotype occurred when the observation was made that single $\mathrm{Lin}^{-} \mathrm{CD} 34^{+} \mathrm{CD} 90^{+}$and not Lin-CD34 ${ }^{+} \mathrm{CD} 90^{-}$cells generated lymphoid and myeloid progeny in both cell culture colony assays and in SCID-hu mice (Baum et al. 1992). Furthermore, virtually all $\mathrm{CD} 34^{+} \mathrm{CD} 90^{+} \mathrm{Lin}^{-}$cells reside in the $\mathrm{CD} 38^{-}$fraction. In a more definitive demonstration of in vivo HSC function using methodology similar to mouse hematopoietic reconstitution assays, human clinical trials of autologous mobilized peripheral blood transplantation revealed that purified $\mathrm{CD} 34^{+} \mathrm{CD} 90^{+}$cells provided longterm engraftment while being purged of unwanted cancer or T cells (Michallet et al. 2000; Negrin et al. 2000; Vose et al. 2001). All of these data combined support the idea that HSCs are contained in the $\mathrm{Lin}^{-} \mathrm{CD} 34^{+} \mathrm{CD} 38^{-} \mathrm{CD} 90^{+}$ population.

Although the phenotype of human HSCs has been welldefined, the identification of the downstream progenitors has been less characterized compared to that in mouse. This specifically includes the immediate downstream MPP that has been comparably well characterized in the mouse (Morrison and Weissman 1994; Morrison et al. 1997; Christensen and Weissman 2001). Clues to the existence of this human MPP population was first demonstrated when retroviral or lentiviral marking of $\mathrm{Lin}^{-} \mathrm{CD} 34^{+} \mathrm{CD} 38^{-}$cells 
before xenotransplantation revealed that single $\mathrm{Lin}^{-} \mathrm{CD} 34^{+}$ CD38 $8^{-}$cells had variable self-renewal and proliferation potential (Guenechea et al. 2001; Mazurier et al. 2004; McKenzie et al. 2006), suggesting that the human MPP lies in this population. Recently, we have identified this candidate MPP population in human cord blood as $\mathrm{Lin}^{-} \mathrm{CD} 34^{+} \mathrm{CD} 38^{-} \mathrm{CD}^{-} 0^{-} \mathrm{CD} 45 \mathrm{RA}^{-}$given its ability for multipotency, incomplete self-renewal capacity, and downstream position from $\mathrm{CD}^{+} 0^{+} \mathrm{CD} 45 \mathrm{RA}^{-}$cells (Majeti et al. 2007). Further downstream from this candidate MPP, early myeloid and lymphoid-committed progenitors have been identified in the human hematopoietic system that give rise to likely counterparts of murine CMP, GMP, and CLP (Fritsch et al. 1993; Ogawa 1993; Galy et al. 1995; Kimura et al. 1997; Manz et al. 2002). Using interleukin-3 (IL-3)R $\alpha$ (a cytokine receptor that when activated supports proliferation and differentiation of primitive progenitors) and CD45RA (an isoform of CD45 that negatively regulates some select classes of cytokine signaling), CMP, GMP, and MEP populations can be identified that are verified by in vitro and in vivo clonality assays (Fig. 1).

\section{PROPERTIES OF HEMATOPOIETIC STEM CELLS}

\section{Stem Cell Fate: Self-renewal versus Differentiation}

HSCs under resting conditions are an asynchronously dividing cell population (Cheshier et al. 1999); when in the absence of injury, the total pool of HSCs remains approximately the same. Accordingly, half of all HSC cell divisions in the total HSC pool must be self-renewing to ensure that stem cell reserves are not exhausted throughout time. Thus, at every point of cell division, an HSC must decide between a process of self-renewal and one of differentiation down the committed progenitor pathway. Although by no means elucidated, important insights have been made to identify the molecular signals that govern this stem cell fate. This particularly includes identifying the genes that regulate HSC self-renewal.

Several developmental regulators of cell fate including Notch (Karanu et al. 2000; Varnum-Finney et al. 2000), HoxB4/HoxA9 (Sauvageau et al. 1995; Thorsteinsdottir et al. 1999, 2002), and Sonic hedgehog (Bhardwaj et al. 2001) have been demonstrated to have roles in selfrenewal of HSCs. In addition, our lab has demonstrated that Wnt signaling is a crucial pathway in regulating selfrenewal in HSCs (Reya et al. 2003). By transducing mouse HSCs with constitutively active $\beta$-catenin, we observed dramatic expansion and long-term growth in culture compared to control HSCs with a subsequent expansion of functional HSCs in vivo. Furthermore, ectopic expression of axin or a frizzled ligand-binding domain, inhibitors of the Wnt signaling pathway, lead to inhibition of HSC growth in vitro and reduced constitution in vivo (Reya et al. 2003).

In contrast to signals that promote self-renewal, signals that limit this potential have also been identified. We have hypothesized that telomere shortening could have a role given the notion that loss of telomere sequence is associated with cellular senescence. Telomerase, an RNA/pro- tein complex responsible for extending telomeric DNA, is expressed by both mouse fetal liver and bone marrow HSCs (Morrison et al. 1996). In addition, telomerase activity is reduced as HSCs differentiate to multipotent progenitor populations, suggesting that such activity correlates with self-renewal capacity (Morrison et al. 1996). However, despite constitutive telomerase activity in HSCs, telomeres still shorten with HSC division in vivo (Notaro et al. 1997; Allsopp et al. 2001; Brummendorf et al. 2001), indicating that such activity is insufficient to maintain telomere length. In addition, serial transplantation of HSCs in mice is limited to approximately five to seven rounds (Harrison et al. 1978; Harrison and Astle 1982), perhaps indicating that HSCs cannot self-renew indefinitely. However, such observations should be interpreted with caution given that serial transplantation is not simply a measure of HSC life span but also a measure of homing to stem cell niches and establishment of appropriate cell-cell interactions within these niches. This caution is justified by the observation that HSCs that constitutively express high levels of TERT fail to have increased numbers of serial passages compared to wild-type HSCs (Allsopp et al. 2003). Nevertheless, the above data suggest an association with inhibition of cellular senescence and HSC self-renewal.

\section{Migration}

Since the emergence of the field of HSC biology, demonstration of stem cell activity has relied on transplantation of candidate stem cells into mouse or other species recipients. For the majority of these assays, cells are injected ectopically from the bone marrow or other classic hematopoietic niches. For successful engraftment to occur, these cells must find their way from the periphery past select tissue barriers to finally end up in hematopoietic microenvironments. This is best indicated by the success of bone marrow transplantation where cells harvested from bone marrow cavities of donors are intravenously injected into patients whose blood-forming system is compromised by radiation or chemotherapy. These cells successfully colonize the ablated bone marrow and reconstitute the entire hematopoietic system. The consistent accuracy of hematopoietic stem and progenitors homing to hematopoietic niches is quite amazing when one thinks about how many potential barriers HSCs must encounter before successful migration. However, it is unclear, a priori, why bone marrow transplantation should be successful. Why should HSCs and progenitors isolated from donor bone marrow accurately home to recipient hematopoietic niches? Is this process simply a random event or do HSCs take advantage of a normal physiologic process: cellular homing from blood to bone marrow?

To begin to examine this question, we first examined the fate of blood-borne HSCs using genetically marked parabiotic mice, which are surgically conjoined and share a common circulation. Through phenotypic and functional analyses, we determined that there are an estimated 100 steady-state HSCs in the blood of the mouse (Wright et al. 2001). When we isolated these HSCs and reintroduced them into the bloodstream, we found that there was 
rapid clearance from the circulation with a resident time between 1 and 5 minutes with subsequent reengraftment, demonstrating that HSCs rapidly migrate through the blood to engraft bone marrow (Wright et al. 2001). To determine whether these HSCs were trafficking to hematopoietic niches, we tracked them with luciferase and found that, indeed, HSCs homed to the bone marrow, liver, and spleen (Cao et al. 2004). In addition, single-cell HSCs that engrafted in the bone marrow exhibited engraftment of different bone marrow compartments (vertebrae, skull, femur, ribs) at different points in time, consistent with the hypothesis that HSCs are in a constant recirculatory flux (Cao et al. 2004). Thus, with respect to the success of bone marrow transplantation, the existence of a physiologic process by which HSCs and progenitors travel from bone marrow to blood and back provides a rationale for such success; the injected cells likely home to bone marrow niches in irradiated recipients because the mechanisms underlying this migration preexist in unmanipulated animals (Wright et al. 2001).

Given that HSCs appear to take advantage of a normal physiologic program of tissue homing, what are the cellular signals that govern this intrinsic mechanism of HSC migration to its respective niches? Although much of the mechanisms that influence HSC migration are not well understood, the extensive studies on lymphocyte homing guide the current hypothesis for HSCs because lymphocytes and HSCs share some similar cellular properties. Accordingly, this includes requiring homing receptor/addressin interactions in the vasculature, followed by chemokine/chemokine receptor interactions, integrin/ receptor binding, and growth/survival factors.

The chemokine receptor CXCR4 and its respective ligand SDF- $1 \alpha$ have been demonstrated to be signals important for HSC migration. Both mouse and human HSCs express CXCR4 (Mohle et al. 1998; Wright et al. 2002), and in cell culture chemotaxis assays, we show that out of a large panel of chemokines, murine HSCs show selective migration only to the CXCR4 ligand SDF-1 $\alpha$ (Wright et al. 2002). Furthermore, mice deficient in CXCR4 or SDF1- $\alpha$ fail to establish bone marrow hematopoiesis (Nagasawa et al. 1996; Zou et al. 1998; Ara et al. 2003), whereas inhibitory antibodies to CXCR4 blocked engraftment of NOD-SCID mice by human HSCs, all consistent with the role for CXCR4/SDF-1 $\alpha$ interactions in HSC homing to bone marrow (Peled et al. 1999).

With respect to the importance of integrin/receptor binding, $\beta 1$ integrin has been shown to have a role in HSC homing. During normal development, colonization of fetal liver, bone marrow, and spleen by HSCs requires the expression and function of $\beta 1$ integrin, which had been implicated in directing the homing of yolk sac, or aortagonad mesonephros (AGM)-derived HSCs, to these tissues (Hirsch et al. 1996; Potocnik et al. 2000). In the adult setting, blocking antibodies against VLA-4 (which is induced by SDF- $1 \alpha$ ), VLA-5 ( $\alpha 5 \beta 1$ ), or their shared subunit $\beta 1$ integrin prevent engraftment of NOD-SCID mice by human HSC-enriched CD $34^{+}$cord blood (Papayannopoulou et al. 1995; Peled et al. 2000). Furthermore, we have shown that inhibition of VLA-4 blocks bone marrow homing and engraftment by murine HSCs (Wagers et al. 2002a). As evidenced by the involvement of select chemokine pathways and integrin/receptor interactions, HSC migration is a dynamic and complex process that involves multiple interactions and signaling pathways.

\section{ORIGIN OF LEUKEMIA STEM CELLS}

Given the observation that the hematopoietic cell hierarchy is tightly regulated at every step from self-renewal of HSCs to differentiation down the progenitor pathway, deregulation of such homeostasis can lead to severe diseases, none the least of which is cancer. Given the observation that cancers are generally monoclonal in nature with heterogeneous cell populations at varying degrees of differentiation, it is not surprising that cancer would be organized in a cellular hierarchy similar to that of the hematopoietic and other tissue-forming systems with a cancer stem cell at the top of the hierarchy. Although the notion that tumors arise from stem cells was first proposed by Cohnheim (1875), it was not until the identification of the leukemia stem cell (LSC) in acute myelogenous leukemia (AML) that experimental evidence demonstrated the existence of a cancer stem cell.

Ever since the first enrichment of an LSC population in a hematological malignancy by Dick and colleagues, much research focus has been on elucidating the genetic and epigenetic events that cause transformation of a normal cell into an LSC as well as the stage of hematopoietic development from which LSCs arise. The first reported enrichment of an LSC was found in human AML when Dick and colleagues found that a small subset of AML cells, $\mathrm{CD} 34^{+} \mathrm{CD} 38^{-}$cells, were able to transplant AML into NOD-SCID and possessed key stem cell properties of differentiation and self-renewal (Lapidot et al. 1994; Bonnet and Dick 1997). Because of the phenotypic similarities between normal HSCs and LSCs, it has been postulated that LSCs arise from HSCs. Given the unique self-renewal property and subsequent long life span of HSCs, this cell population would be most ideal to acquire multiple mutations required for leukemic transformation. However, subsequent experiments demonstrated that AML LSCs, unlike HSCs, do not express CD90 (Thy1) (Blair et al. 1997; Miyamoto et al. 2000). These observations led to two hypotheses on the origin of the LSC: (1) AML LSCs originate from HSCs but aberrantly lose expression of CD90 during transformation or (2) AML LSC transformation occurs in a downstream committed progenitor cell. To test these hypotheses, we first investigated the cell surface phenotypes in AML-ETO1 translocation-associated AML patients who were atomic bomb survivors from Hiroshima. Consistent with previous studies, we found that the AML LSC was found in the $\mathrm{Lin}^{-} \mathrm{CD} 34^{+} \mathrm{CD}^{-} 8^{-} \mathrm{CD}^{-} 0^{-}$(Fig. 2). However, when the bone marrow of long-term disease-free patients was analyzed, the AML1-ETO translocation was detected in $\mathrm{Lin}^{-} \mathrm{CD} 34^{+}$ $\mathrm{CD} 38^{-} \mathrm{CD}^{+} 0^{+}$nonleukemic HSCs that gave rise to normal multilineage colonies in vitro. Interestingly, up to $40 \%$ of these HSCs possessed the AML-ETO1 translocation, whereas patients in remission retained approximately $1 \%$ of their HSCs as AML1-ETO-positive over several years posttreatment (Miyamoto et al. 2000). These observations led to an important conclusion: The AML1-ETO translocation is 
A

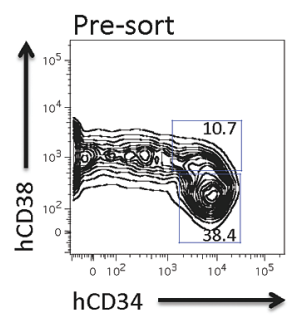

B

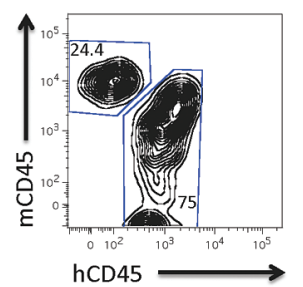

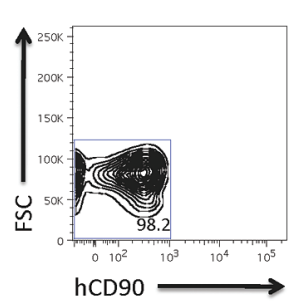
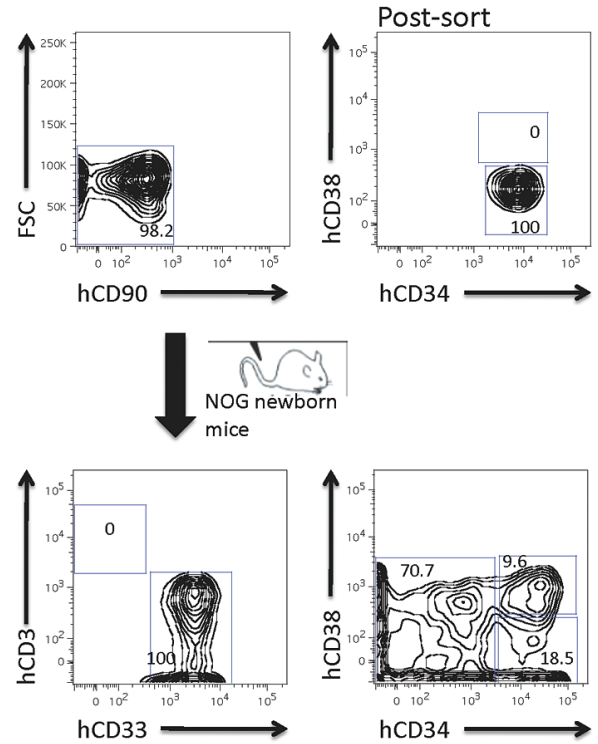

C

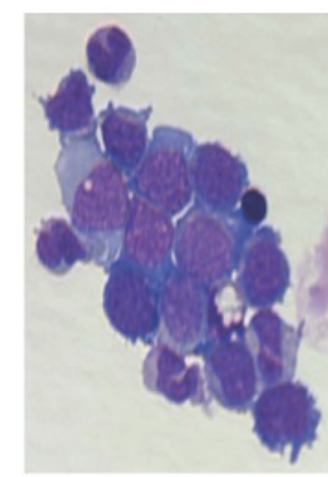

Figure 2. Cell surface phenotype of AML LSC. $(A)$ Cell surface expression profile of bone marrow cells from a representative human AML patient. Lineage (CD3, CD19, CD20)-positive cells are gated out. The AML LSC (Lin ${ }^{-} \mathrm{CD} 34^{+} \mathrm{CD} 38^{-} \mathrm{CD} 90^{-}$) population was prospectively isolated and injected via facial vein into NOD/SCID/IL2R $\gamma^{-1}$ (NOG) pups. (B) Engraftment of human LSCs in mouse bone marrow after 10 weeks shows exclusively myeloid engraftment with recapitulation of $\mathrm{CD} 34^{-}, \mathrm{CD} 34^{+} \mathrm{CD} 38^{+}$, and $\mathrm{CD} 34^{+} \mathrm{CD} 38^{-}$ populations. $(C)$ Wright-Giemsa staining of purified human $C D 45^{+}$cells indicates the presence of leukemia cells in recipient mouse bone marrow with blast morphology. (Image courtesy of Ravindra Majeti and Chris Park.)

necessary, but not sufficient, to induce leukemogenesis and occurs in an HSC population that is preleukemic. This conclusion was further substantiated by experiments involving transgenic mice expressing AML1-ETO driven from the MRP8 promoter. The MRP8 gene encodes a small calciumbinding protein of the $\mathrm{S} 100$ family that is only expressed in neutrophils, monocytes, and their immediate progenitors, CMPs and GMPs, but not HSCs (Lagasse and Weissman 1992). These hMRP8AML1-ETO transgenic mice were healthy with no evidence of leukemia; only after these mice were treated with a DNA alkylating mutagen did they develop leukemias (Yuan et al. 2001). To additionally address the possibility of a committed progenitor as the AML LSC, we investigated the role of the MLL-ENL translocation in the mouse hematopoietic system. The MLL-ENL translocation is frequently associated with the development of acute myeloid and lymphoid leukemias and has been shown to induce AML in mice (Lavau et al. 2000; Ayton and Cleary 2001; Cozzio et al. 2003). We retrovirally transduced the MLL-ENL fusion gene into prospectively sorted HSCs and downstream myeloid progenitors and found that transduction of HSCs, CMPs, or GMPs by MLLENL induced the exact same AML in vitro and in vivo, demonstrating that mutations in committed progenitors can initiate AML (Cozzio et al. 2003). To further elucidate the exact progenitor stage of LSC transformation, we recently showed that normal primitive hematopoietic cells (Lin ${ }^{-} \mathrm{CD} 34^{+} \mathrm{CD} 38^{-} \mathrm{CD}^{-} 0^{-} \mathrm{CD} 45 \mathrm{RA}^{-}$) exhibiting a phenotype similar to that of LSC are multipotent progenitors, suggesting that AML stem cells could originate from this normally non-self-renewing population (Majeti et al. 2007). Therefore, in the case of AML, the LSC likely arises not at the stage of HSC, but rather at a later stage of differentiation. Given these observations in AML, our lab then investigated other leukemia types to test this hypothesis.

Part of our investigation first turned to chronic myelogenous leukemia (CML). In 1977, Fialkow et al. (1977) first demonstrated by allelic $\mathrm{X}$ chromosomal markers that CML originates in a multipotent hematopoietic cell with expression of the canonical BCR-ABL translocation. Years later, our lab demonstrated that chronic phase CML HSCs harbor the BCR-ABL translocation (Jamieson et al. 2004b). These $\mathrm{BCR}-\mathrm{ABL}^{+} \mathrm{HSC}$ s outcompete their BCR-ABL ${ }^{-} \mathrm{HSC}$ counterparts while simultaneously not increasing overall stem cell frequency. Correlating these findings in the mouse, we found that a chronic phase CML syndrome could be induced by blocking the expression of the transcription factor JunB with only HSCs and not progenitor populations capable of transplanting this CML-like disease (Passegué et al. 2004). Given these results, it is likely that in the chronic phase of CML, the transformation to LSC was at the HSC level. However, the pathogenesis of CML is triphasic, with transformation to a more acute leukemia phenotype occurring in the accelerated and blast crisis phases. Therefore, during the more aggressive accelerated and blast crisis phases of CML, is leukemic transformation at the level of the HSC or a committed progenitor? To first address this question, we determined whether other populations besides the HSC could initiate CML in a mouse model. We generated hMRP8p $210^{\mathrm{BCR}-\mathrm{ABL}}$ transgenic mice in which the hMRP8 promoter expression of BCR-ABL is targeted exclusively to myeloid progenitors and progeny and is specifically absent on HSC. Interestingly, these mice developed a human CML-like disease, suggesting that a cell 
downstream from HSC could be the ultimate target of later leukemic transformation (Jaiswal et al. 2003). To support this notion in a more definitive matter, our lab examined CML patients during the chronic, accelerated, and myeloid blast crisis phases to determine population differences in stem cell potential. Interestingly, we found that in the blast crisis phase, the only cell population that was increased in frequency (besides the blast population) was the granulocyte-macrophage progenitor (GMP) population. In addition, BCR-ABL amplification occurred in the GMP population, whereas BCR-ABL transcript levels in HSCs remained constant during progression from chronic phase to blast crisis. In looking at $\beta$-catenin expression through CML disease progression, we found that GM progenitors in accelerated phase or blast crisis had increased $\beta$-catenin levels compared to GM progenitors in chronic phase or normal controls. Additionally, HSCs from chronic, accelerated, and blast crisis phase CML as well as normal HSCs all had similar levels of activated $\beta$ catenin, which was significantly lower than activated levels in blast crisis GMPs. Furthermore, these GMPs demonstrated aberrant self-renewal in vitro in a methylcellulose replating assay in which normal GM progenitors could not (Jamieson et al. 2004a,b). This GMP population, and not CML blasts, transplants into immunodeficient mice and can be serially transplanted into secondary mouse recipients, demonstrating in vivo self-renewal stem cell function (C.H. Jamieson, pers. comm.). Thus, it appears that in blast crisis CML, as with AML, the LSC arises from a committed progenitor population, the GMP, which has aberrantly acquired the ability to self-renew.

\section{PROPERTIES OF LEUKEMIA STEM CELLS}

\section{Self-renewal}

Like normal HSCs, a key requirement of LSCs is the ability to self-renew in order to propagate leukemic disease. Several signaling pathways including Wnt/ $\beta$ catenin (Reya et al. 2003), Hox (Argiropoulos and Humphries 2007), and Bmi-1 (Raaphorst 2003) have been implicated in self-renewal roles for both normal and leukemic hematopoiesis. However, the normal homeostatic mechanisms regulating self-renewal in HSCs are likely disrupted in LSCs. First, we have demonstrated such abnormal self-renewal signaling in the Wnt/ $\beta$ catenin pathway. As mentioned in CML, the candidate LSC in blast crisis, the GMP population, has significantly higher levels of nuclear active $\beta$-catenin compared to both CML HSCs and normal GMPs, which directly contributes to its ability to aberrantly self-renew in vitro and in vivo (Jamieson et al. 2004b). The abnormal self-renewing properties of the CML GMP can be subsequently inhibited by axin, an inhibitor of $\beta$-catenin.

Hox genes have also been implicated in self-renewal in both normal and abnormal hematopoiesis and have a role in stem and progenitor expansion. Hyperexpression of HoxB4 leads to expansion of the HSC pool (Sauvageau et al. 1995), whereas forced expression of Hoxa9, Hoxa10, Hoxb3, $H o x b 6$, and Hoxb8 confers a growth advantage in vitro and in vivo and leads to long latency leukemia (for review, see
Argiropoulos and Humphries 2007). Regulators of Hox gene expression are also aberrantly regulated in human leukemias. One such regulator is the mixed-lineage leukemia (MLL) transcription factor that is required for normal hematopoiesis, encoding chromatin modifiers that are required for proper maintenance of Hox gene expression. Rearrangements involving MLL fusion genes constitute $5 \%$ of all AML cases and $22 \%$ of those with acute lymphoblastic leukemia (Sauvageau et al. 1995; De Braekeleer et al. 2005). In our studies, we have shown that retroviral insertion of a leukemogenic MLL-ENL fusion gene into normal hematopoietic stem and progenitor cells induces an AML phenotype in vitro and in vivo, endowing the normally non-self-renewing committed progenitor populations with aberrant self-renewal properties evidenced by their ability for serial replating of methylcellulose colonies (Cozzio et al. 2003). We also observed similar acquisition of long-term self-renewal properties in multipotent progenitors when another MLL fusion gene, MLL-GAS7, was retrovirally inserted into HSC and early progenitors, which resulted in mixed-lineage leukemias (So et al. 2003).

Other molecular pathways involved in self-renewal in normal hematopoiesis that might also be implicated in leukemia include Bmi-1 (for review, see Raaphorst 2003). In 2003, we and other investigators demonstrated that $B m i-1$ has a crucial role in the self-renewal of LSCs. Fetal liver cells from $B m i-1^{-/}$mice were retrovirally transduced with Hox9 and Meisla oncogenes (which generate a well-characterized myeloid leukemia; Kroon et al. 1998) and were transplanted into syngeneic mouse hosts. In the resulting leukemia that developed, $B m i-1^{-1-}$ bone marrow leukemia cells were unable to form secondary transplants and were less efficient at generating leukemia colony-forming cells compared to Bmi-1 wild-type leukemia cells (Lessard and Sauvageau 2003). We then investigated the relative expression levels of $B m i-1$ within the hematopoietic cell hierarchy by generating green fluorescent protein (GFP) knockin mice expressed under endogenous transcriptional regulatory elements of the $B m i-1$ gene. We found that Bmi-1 is expressed in HSCs at its highest levels and down-regulated upon commitment to differentiation (Hosen et al. 2007). Looking at two murine leukemia models induced by $\mathrm{p} 210 \mathrm{BCR} / \mathrm{ABL}$ or TEL/PDGF $\beta$ R + AML1/ETOm we found that expression of Bmi-1 was highest in leukemic HSCs compared to downstream progenitors, albeit at similar expression levels compared to normal HSCs (Hosen et al. 2007).

\section{Programmed Cell Death}

Given the general hallmark of tumor cells to escape homeostatic controls that allow unregulated proliferation, tumor cells must have aberrant abilities to escape apoptosis, a key regulator of proliferative homeostasis. Indeed, this is the case for acute leukemias and LSCs. Because the down-regulation of apoptosis is generally a key feature of tumor pathogenesis, it is not surprising that acute leukemias and LSCs have deregulated apoptotic signaling. The antiapoptotic gene $\mathrm{Bcl}-2$ has long been shown to have a role in lymphoid malignancies, with a growing body of evidence suggesting that deregulation of $\mathrm{Bcl}-2$ is important 
in the leukemic transformation of myeloid cells. Leukemia cells from most human AML subtypes have been found to express $\mathrm{Bcl}-2$ at levels significantly higher than their normal cellular counterparts (Delia et al. 1992; Bensi et al. 1995) as well as highest levels of Bcl-2 expression found in early LSC progenitors (Konopleva et al. 2002). In a mouse model overexpressing the $B c l-2$ gene driven by the major histocompatibility complex (MHC) class I promoter, HSCs were more resistant to radiation-induced apoptosis than wild-type HSCs, and these mice possessed a larger HSC compartment (Domen et al. 1998), suggesting that $\mathrm{Bcl}-2$ has a specific role in the protection of HSCs from apoptosis with possibly similar behavior in the LSC population. Despite this, overexpression of $\mathrm{Bcl}-2$ in transgenic murine models has been found to be relatively benign in terms of cellular transformation (Cory et al. 1994), suggesting that additional oncogenic mutations are needed for transformation. We showed that enforced expression of $\mathrm{Bcl}-2$ in the myeloid lineage with the hMRP8 promoter allows monocytes from these mice to survive in culture in the absence of serum or exogenous growth factors compared to wildtype cells rapidly undergoing apoptosis, suggesting that Bcl-2 expression may promote a prolonged cellular survival that would allow a greater possibility of acquiring additional oncogenic mutations. In line with this hypothesis, we have shown that enforced $\mathrm{Bcl}-2$ expression greatly increases the incidence of CML-like disease in hMRP $8^{\mathrm{BCR}-}$ ${ }^{\mathrm{ABL}} \mathrm{hMRP} 8^{\mathrm{Bcl}-2}$ double transgenic mice (Jaiswal et al. 2003), as well as the incidence of acute promyelocytic leukemia in hMRP8 $8^{\mathrm{PML} / \mathrm{RAR} \alpha} \mathrm{hMRP} 8^{\mathrm{Bcl}-2}$ double transgenic mice (Kogan et al. 2001).

In addition to $\mathrm{Bcl}-2$, we have shown that the proapoptotic Fas pathway might be involved in myeloid leukemia pathogenesis. Loss-of-function mutations in the Fas receptor (CD95) or in components of the Fas signaling pathway have been implicated in several human AMLs (Robertson et al. 1995; Bouscary et al. 1997). Furthermore, human $\mathrm{CD} 34^{+} \mathrm{CD} 38^{-} \mathrm{AML}$ progenitors express lower levels of Fas/Fas-ligand and Fas-induced apoptosis compared to CD $34^{+} \mathrm{CD} 38^{+}$blasts (Costello et al. 2000). To further assess the role of the Fas pathway in AML leukemogenesis, we crossed hMRP8Bcl-2 and Fas-deficient Faslpr/lpr mice and observed the development of AML in $15 \%$ of these crossed mice but not in either of the individual mice strains (Traver et al. 1998). These results suggest that $\mathrm{Bcl}$ 2 and the Fas receptor regulate two distinct apoptotic pathways in myeloid cells, with changes in both that are sufficient to induce AML at a low frequency.

Altogether, these observations demonstrate that the prevention of cell death through either up-regulation of antiapoptotic signals or down-regulation of proapoptotic signals is an important event in the cellular transformation to myeloid leukemias.

\section{Immune Surveillance}

Many tumors have mechanisms that function in the evasion of immune surveillance, mechanisms that contribute to disease pathogenesis. For example, tumors can downregulate components of the MHC class I antigen-processing pathway to avoid recognition by cytotoxic $\mathrm{T}$ lymphocytes, secrete immunosuppressive cytokines, or use methods to evade the innate immune system. We have recently identified CD47 as having a role in immune evasion in AML. CD47, a cell surface protein also known as integrin-associated protein, is known among other functions to inhibit phagocytosis by macrophages and other immune effector cells by binding its ligand signal regulatory protein $\alpha(\operatorname{Sirp} \alpha)$ on phagocytes. We have shown that CD47 is up-regulated on mouse and human bulk leukemia cells as well as LSCs in both CML and AML compared to normal cellular counterparts (S. Jaiswal et al.; R. Majeti and M.P. Chao; both in prep.). In addition, enforced CD47 expression facilitates engraftment of human leukemia cells in immunodeficient mice that otherwise cannot engraft ( $S$. Jaiswal et al., in prep.). Furthermore, antibody blockade of the CD47-Sirp $\alpha$ interaction causes human leukemia cells that normally evade phagocytosis to become engulfed and eliminated by macrophages (R. Majeti and M.P. Chao, in prep.). Altogether, the identification of pathways that regulate evasion of immune surveillance in AML LSCs could provide insight into a new avenue of leukemic biology as well as represent a potential therapeutic target.

\section{A MULTISTEP MODEL OF MYELOID LEUKEMIA PROGRESSION}

In both AML and CML, we observed that initial leukemic mutations (AML1-ETO in AML and BCR-ABL in CML) are found in the HSC population and that leukemia initiated at the HSC level likely represents an initial leukemic phase that is chronic in nature. Rather, it appears that multiple independent genetic and epigenetic changes must occur to drive leukemia to a more aggressive phase, which is marked by LSC transformation at the committed progenitor level. For example, in the case of CML, studies have shown that $30-75 \%$ of normal, healthy individuals possess the BCRABL translocation in a minority of peripheral blood leukocytes (Biernaux et al. 1996; Bose et al. 1998). In addition, in our hMRP8p210 $0^{\mathrm{BCR}-\mathrm{ABL}}$ transgenic mouse model, these mice developed a disease similar to human chronic phase CML. However, hMRP8p210 ${ }^{\mathrm{BCR}-\mathrm{ABL}}$ mice crossed with apoptosis-resistant hMRP8Bcl-2 mice induced a blast crisis disease in $50 \%$ of the mice, again suggesting that additional mutations are necessary for the progression from chronic phase to blast crisis CML (Jaiswal et al. 2003). For perpetual propagation of leukemic mutations to occur, these mutations must occur in a cell population that can self-renew, otherwise the short life of a committed cell would not sustain these oncogenic events. Given that normally committed hematopoietic progenitors are targets for LSC transformation in AML and CML, it is probable that these downstream progenitors undergo several oncogenic events over time that ultimately lead to aberrant self-renewal, which then escape homeostatic controls and ultimately lead to proliferative leukemia (Fig. 3).

\section{CONCLUSIONS}

Both the mouse and human hematopoietic systems consist of a tightly regulated cellular hierarchy that is governed by step-by-step lineage restriction correlating with 
- Progression to acute myelogenous leukemia (AML) or myeloid blast crisis, $\mathrm{CML}$

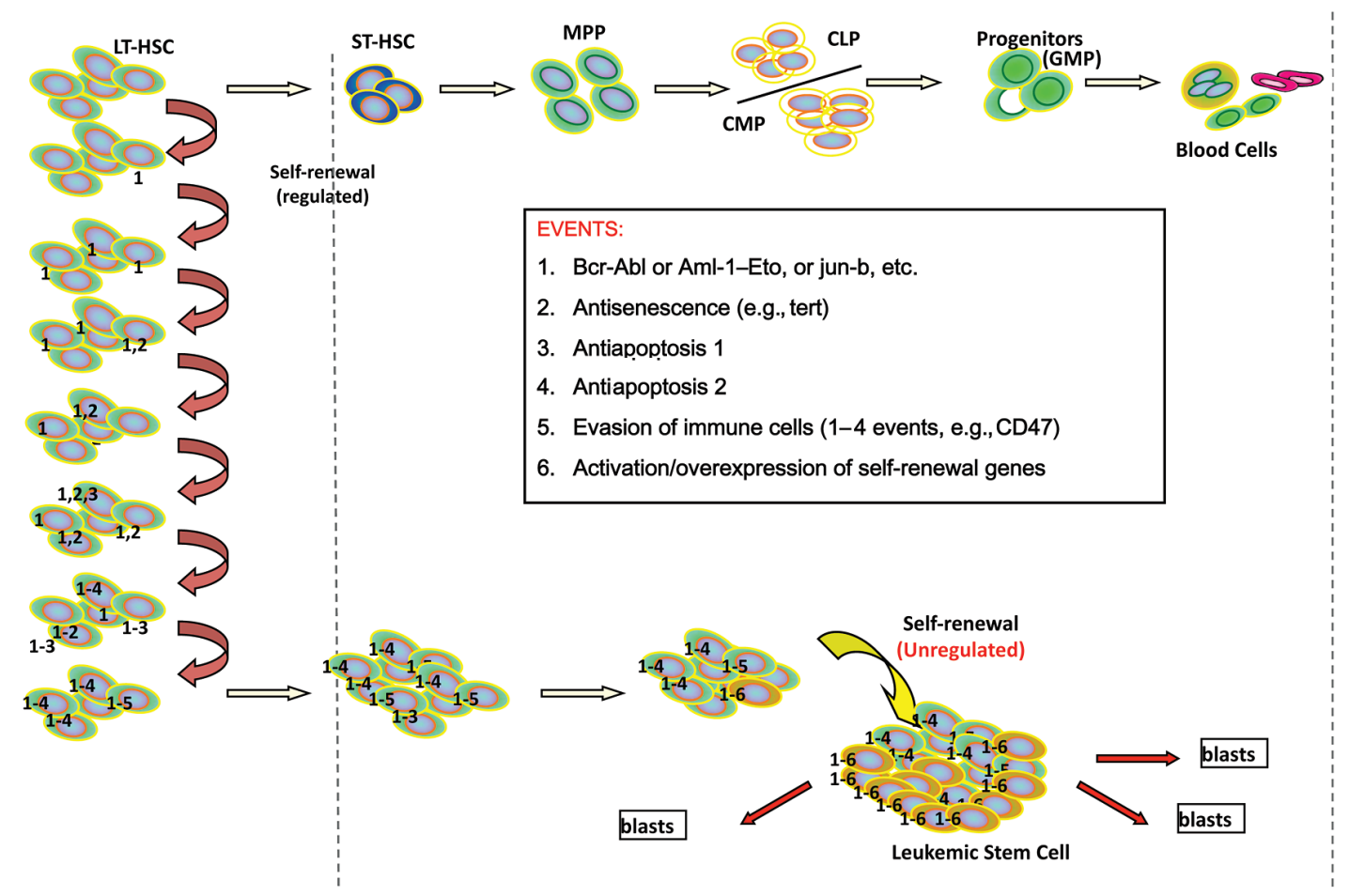

Figure 3. Multistep model of progression to AML or blast crisis CML. HSCs undergo differentiation to myeloid lineages in a quantal fashion (top). Given their long cellular life, HSCs acquire initial mutations that get passed down to self-renewing clonal HSCs. These HSC clones acquire further mutations or epigenetic events until the accumulation of multiple mutations and epigenesis leads to acquisition of aberrant self-renewal properties, with transformation of the HSC to the LSC. These LSCs then lead to a proliferation of leukemic blasts.

gradual loss of self-renewal. Identification and characterization of hematopoietic stem and progenitor cells have led to the success of bone marrow transplantation for a variety of human diseases and have provided precedence for the therapeutic potential of tissue-forming stem cells in other organ systems. However, the unique properties that separate HSCs from committed progenitors, including selfrenewal, multipotency, cell survival, and migration, can also be aberrantly deregulated leading to the transformation of the HSCs into LSCs. Indeed, LSCs abnormally activate self-renewal pathways and antiapoptotic signals and possess metastatic features consistent with a loss in normal stem cell homeostasis. Although several genetic events have been identified in the transformation of normal hematopoietic stem and progenitor cells into LSCs, work must be done to identify all of the events that are necessary and sufficient for leukemogenesis.

Such elucidation can then lead to the identification of the sequential progression of these events and determine whether the progression is always similar across patients. One can then imagine being able to genetically profile a leukemia patient for these mutations and subsequently determine the stage of leukemia. In addition, knowledge of such events as well as determining the genetic and cellular differences between LSC and normal HSC will lead to novel therapies that eradicate the initiator of tumorigenesis, the cancer stem cell.

\section{ACKNOWLEDGMENTS}

We thank Siddhartha Jaiswal, Ravindra Majeti, Catriona Jamieson, Deepta Bhattacharya, Agnieszka Czechowicz, and Lisa Ooi for contributing data cited in this work. We also thank Derrick Rossi and David Bryder for manuscript assistance. M.P.C. is supported by a Howard Hughes Medical Institute Medical Fellowship and J.S. is supported by a fellowship from the California Institute for Regenerative Medicine. This research is supported by National Institutes of Health grant R01CA86017 to I.L.W.

\section{REFERENCES}

Adolfsson, J., Månsson, R., Buza-Vidas, N., Hultquist, A., Liuba, K., Jensen, C.T., Bryder, D., Yang, L., Borge, O.J., Thoren, L.A., et al. 2005. Identification of Flt $3^{+}$lympho-myeloid stem cells lacking erythro-megakaryocytic potential a revised road map for adult blood lineage commitment. Cell 121: 295-306.

Akashi, K., Traver, D., Miyamoto, T., and Weissman, I.L. 2000. A clonogenic common myeloid progenitor that gives rise to all myeloid lineages. Nature 404: 193-197.

Allsopp, R.C., Cheshier, S., and Weissman, I.L. 2001. Telomere shortening accompanies increased cell cycle activity during serial transplantation of hematopoietic stem cells. J. Exp. Med. 193: 917-924.

Allsopp, R.C., Morin, G.B., Horner, J.W., DePinho, R., Harley, C.B., and Weissman, I.L. 2003. Effect of TERT over-expression on the long-term transplantation capacity of hematopoietic stem cells. Nat. Med. 9: 369-671.

Ara, T., Tokoyoda, K., Sugiyama, T., Egawa, T., Kawabata, K., 
and Nagasawa, T. 2003. Long-term hematopoietic stem cells require stromal cell-derived factor-1 for colonizing bone marrow during ontogeny. Immunity 19: 257-267.

Argiropoulos, B. and Humphries, R.K. 2007. Hox genes in hematopoiesis and leukemogenesis. Oncogene 26: 6766-6776.

Arinobu, Y., Mizuno, S., Chong, Y., Shigematsu, H., Iino, T. Iwasaki, H., Graf, T., Mayfield, R., Chan, S., Kastner, P., and Akashi, K. 2007. Reciprocal activation of GATA-1 and PU.1 marks initial specification of hematopoietic stem cells into myeloerythroid and myelolymphoid lineages. Cell Stem Cell 1: 416-427.

Ayton, P.M. and Cleary, M.L. 2001. Molecular mechanisms of leukemogenesis mediated by MLL fusion proteins. Oncogene 20: 5695-5707.

Baum, C.M., Weissman, I.L., Tsukamoto, A.S., Buckle, A.M., and Peault, B. 1992. Isolation of a candidate human hematopoietic stem-cell population. Proc. Natl. Acad. Sci. 89: 2804-2808

Becker, A.J., McCulloch, C.E., and Till, J.E. 1963. Cytological demonstration of the clonal nature of spleen colonies derived from transplanted mouse marrow cells. Nature 197: 452-454.

Bensi, L., Longo, R., Vecchi, A., Messora, C., Garagnani, L., Bernardi, S., Tamassia, M.G., and Sacchi, S. 1995. Bcl-2 oncoprotein expression in acute myeloid leukemia. Haematologica 80: 98-102.

Bhardwaj, G., Murdoch, B., Wu, D., Baker, D.P., Williams, K.P., Chadwick, K., Ling, L.E., Karanu, F.N., and Bhatia, M. 2001. Sonic hedgehog induces the proliferation of primitive human hematopoietic cells via BMP regulation. Nat. Immunol. 2: 172-180.

Bhatia, M., Wang, J.C., Kapp, U., Bonnet, D., and Dick, J.E. 1997. Purification of primitive human hematopoietic cells capable of repopulating immune-deficient mice. Proc. Natl. Acad. Sci. 94: 5320-5325.

Biernaux, C., Sels, A., Huez, G., and Stryckmans, P. 1996. Very low level of major BCR-ABL expression in blood of some healthy individuals. Bone Marrow Transplant. (suppl. 3) 17: S45-S47.

Blair, A., Hogge, D.E., Ailles, L.E., Lansdorp, P.M., and Sutherland, H.J. 1997. Lack of expression of Thy-1 (CD90) on acute myeloid leukemia cells with long-term proliferative ability in vitro and in vivo. Blood 89: 3104-3112.

Bonnet, D. and Dick, J.E. 1997. Human acute myeloid leukemia is organized as a hierarchy that originates from a primitive hematopoietic cell. Nat. Med. 3: 730-737.

Bose, S., Deininger, M., Gora-Tybor, J., Goldman, J.M., and Melo, J.V. 1998. The presence of typical and atypical BCRABL fusion genes in leukocytes of normal individuals: Biologic significance and implications for the assessment of minimal residual disease. Blood 92: 3362-3367.

Bouscary, D., De Vos, J., Guesnu, M., Jondeau, K., Viguier, F., Melle, J., Picard, F., Dreyfus, F., and Fontenay-Roupie, M. 1997. Fas/Apo-1 (CD95) expression and apoptosis in patients with myelodysplastic syndromes. Leukemia 11: 839-845.

Brummendorf, T.H., Rufer, N., Baerlocher, G.M., Roosnek, E., and Lansdorp, P.M. 2001. Limited telomere shortening in hematopoietic stem cells after transplantation. Ann. N.Y. Acad. Sci. 938: 1-8.

Cao, Y.A., Wagers, A.G., Beilhack, A., Dusich, J., Bachmann, M.H., Negrin, R.S., Weissman, I.L., and Contag, C.H. 2004. Shifting foci of hematopoiesis during reconstitution from single stem cells. Proc. Natl. Acad. Sci. 101: 221-226.

Cheshier, S.H., Morrison, S.J., Liao, X., and Weissman, I.L. 1999. In vivo proliferation and cell cycle kinetics of long-term self-renewing hematopoietic stem cells. Proc. Natl. Acad. Sci. 96: $3120-3125$.

Christensen, J.L. and Weissman, I.L. 2001. Flk-2 is a marker in hematopoietic stem cell differentiation: A simple method to isolate long-term stem cells. Proc. Natl. Acad. Sci. 98: 1454114546.

Civin, C.I., Strauss, L.C., Brovall, C., Fackler, M.J., Schwartz, J.F., and Shaper, J.H. 1984. Antigenic analysis of hematopoiesis. III. A hematopoietic progenitor cell surface antigen defined by a monoclonal antibody raised against $\mathrm{KG}-1 \mathrm{a}$ cells. J. Immunol. 133: $157-165$.
Cohnheim, V. 1875. Congenitales, quergestreiftes muskelsarkom der nieren. Virchows Arch. Pathol. Anat. Physiol. Klin. Med. 65: $64-69$.

Cory, S., Harris, A.W., and Strasser, A. 1994. Insights from transgenic mice regarding the role of $b c l-2$ in normal and neoplastic lymphoid cells. Philos. Trans. R. Soc. Lond. B Biol. Sci. 345: 289-295.

Costello, R.T., Mallet, F., Gaugler, B., Sainty, D., Arnoulet, C., Gastaut, J.A., and Olive, D. 2000. Human acute myeloid leukemia $\mathrm{CD} 34^{+} / \mathrm{CD} 38^{-}$progenitor cells have decreased sensitivity to chemotherapy and Fas-induced apoptosis, reduced immunogenicity, and impaired dendritic cell transformation capacities. Cancer Res. 60: 4403-4411.

Cozzio, A., Passegué, E., Ayton, P.M., Karsunky, H., Cleary, M.L., and Weissman, I.L. 2003. Similar MLL-associated leukemias arising from self-renewing stem cells and shortlived myeloid progenitors. Genes Dev. 17: 3029-3035.

De Braekeleer, M., Morel, F., Le Bris, M.J., Herry, A., and Douet-Guilbert, N. 2005. The MLL gene and translocations involving chromosomal band 11q23 in acute leukemia. Anticancer Res. 25: 1931-1944.

Delia, D., Aiello, A., Soligo, D., Fontanella, E., Melani, C., Pezzella F., Pierotti, M.A., and Della Porta, G. 1992. bcl-2 proto-oncogene expression in normal and neoplastic human myeloid cells. Blood 79: 1291-1298.

DiGiusto, D., Chen, S., Combs, J., Webb, S., Namikawa, R., Tsukamoto, A., Chen, B.P., and Galy, A.H. 1994. Human fetal bone marrow early progenitors for $\mathrm{T}, \mathrm{B}$, and myeloid cells are found exclusively in the population expressing high levels of CD34. Blood 84: 421-432.

Domen, J., Gandy, K.L., and Weissman, I.L. 1998. Systemic overexpression of BCL-2 in the hematopoietic system protects transgenic mice from the consequences of lethal irradiation. Blood 91: 2272-2282.

Fialkow, P.J., Jacobson, R.J., and Papayannopoulou, T. 1977. Chronic myelocytic leukemia: Clonal origin in a stem cell common to the granulocyte, erythrocyte, platelet and monocyte/macrophage. Am. J. Med. 63: 125-130.

Forsberg, E.C., Serwold, T., Kogan, S., Weissman, I.L., and Passegué, E. 2006. New evidence supporting megakaryocyteerythrocyte potential of flk $2 / \mathrm{flt}^{+}$multipotent hematopoietic progenitors. Cell 126: 415-426.

Fritsch, G., Buchinger, P., Printz, D., Fink, F.M., Mann, G., Peters, C., Wagner, T., Adler, A., and Gadner, H. 1993. Rapid discrimination of early $\mathrm{CD} 34^{+}$myeloid progenitors using CD45-RA analysis. Blood 81: 2301-2309.

Galy, A., Travis, M., Cen, D., and Chen, B. 1995. Human T, B, natural killer, and dendritic cells arise from a common bone marrow progenitor cell subset. Immunity 3: 459-473.

Guenechea, G., Gan, O.I., Dorrell, C., and Dick, J.E. 2001. Distinct classes of human stem cells that differ in proliferative and self-renewal potential. Nat. Immunol. 2: 75-82.

Hao, Q.L., Smogorzewska, E.M., Barsky, L.W., and Crooks, G.M. 1998. In vitro identification of single CD $34^{+} \mathrm{CD} 38^{-}$ cells with both lymphoid and myeloid potential. Blood 91: 4145-4151.

Hao, Q.L., Thiemann, F.T., Petersen, D., Smogorzewska, E.M., and Crooks, G.M. 1996. Extended long-term culture reveals a highly quiescent and primitive human hematopoietic progenitor population. Blood 88: 3306-3313.

Harrison, D.E. and Astle, C.M. 1982. Loss of stem cell repopulating ability upon transplantation. Effects of donor age, cell number, and transplantation procedure. J. Exp. Med. 156: 1767-1779.

Harrison, D.E., Astle, C.M., and Delaittre, J.A. 1978. Loss of proliferative capacity in immunohemopoietic stem cells caused by serial transplantation rather than aging. J. Exp. Med. 147: 1526-1531.

Hirsch, E., Iglesias, A., Potocnik, A.J., Hartmann, U., and Fassler, R. 1996. Impaired migration but not differentiation of haematopoietic stem cells in the absence of $\beta 1$ integrins. Nature 380: 171-175.

Hosen, N., Yamane, T., Muijtjens, M., Pham, K., Clarke, M.F., and Weissman, I.L. 2007. Bmi-1-green fluorescent protein- 
knock-in mice reveal the dynamic regulation of bmi-1 expression in normal and leukemic hematopoietic cells. Stem Cells 25: $1635-1644$

Huang, S. and Terstappen, L.W. 1994. Lymphoid and myeloid differentiation of single human CD34 $4^{+}$, HLA-DR ${ }^{+}, \mathrm{CD} 38^{-}$ hematopoietic stem cells. Blood 83: 1515-1526.

Ikuta, K. and Weissman, I.L. 1992. Evidence that hematopoietic stem cells express mouse $c$-kit but do not depend on steel factor for their generation. Proc. Natl. Acad. Sci. 89: 1502-1506.

Jaiswal, S., Traver, D., Miyamoto, T., Akashi, K., Lagasse, E., and Weissman, I.L. 2003. Expression of $B C R / A B L$ and $B C L$ 2 in myeloid progenitors leads to myeloid leukemias. Proc. Natl. Acad. Sci. 100: 10002-10007.

Jamieson, C.H., Weissman, I.L., and Passegué, E. 2004a. Chronic versus acute myelogenous leukemia: A question of selfrenewal. Cancer Cell 6: 531-533.

Jamieson, C.H., Ailles, L.E., Dylla, S.J., Muijtjens, M., Jones, C., Zehnder, J.L., Gotlib, J., Li, K., Manz, M.G., Keating, A., Sawyers, C.L., and Weissman, I.L. 2004b. Granulocyte-macrophage progenitors as candidate leukemic stem cells in blast-crisis CML. N. Engl. J. Med. 351: 657-667.

Karanu, F.N., Murdoch, B., Gallacher, L., Wu, D.M., Koremoto, M., Sakano, S., and Bhatia, M. 2000. The Notch ligand Jagged1 represents a novel growth factor of human hematopoietic stem cells. J. Exp. Med. 192: 1365-1372.

Kiel, M.J., Yilmaz, O.H., Iwashita, T., Yilmaz, O.H., Terhorst, C., and Morrison, S.J. 2005. SLAM family receptors distinguish hematopoietic stem and progenitor cells and reveal endothelial niches for stem cells. Cell 121: 1109-1121.

Kimura, T., Sakabe, H., Tanimukai, S., Abe, T., Urata, Y., Yasukawa, K., Okano, A., Taga, T., Sugiyama, H., Kishimoto, T., and Sonoda, Y. 1997. Simultaneous activation of signals through gp130, c-kit, and interleukin-3 receptor promotes a trilineage blood cell production in the absence of terminally acting lineage-specific factors. Blood 90: 4767-4778.

Kogan, S.C., Brown, D.E., Shultz, D.B., Truong, B.T., Lallemand-Breitenbach, V., Guillemin, M.C., Lagasse, E., Weissman, I.L., and Bishop, J.M. 2001. BCL-2 cooperates with promyelocytic leukemia retinoic acid receptor $\alpha$ chimeric protein (PMLRAR $\alpha$ ) to block neutrophil differentiation and initiate acute leukemia. J. Exp. Med. 193: 531-543.

Kondo, M., Weissman, I.L., and Akashi, K. 1997. Identification of clonogenic common lymphoid progenitors in mouse bone marrow. Cell 91: 661-672.

Konopleva, M., Zhao, S., Hu, W., Jiang, S., Snell, V., Weidner, D., Jackson, C.E., Zhang, X., Champlin, R., Estey, E., Reed, J.C., and Andreeff, M. 2002. The anti-apoptotic genes $B c l-X_{L}$ and $\mathrm{Bcl}-2$ are over-expressed and contribute to chemoresistance of non-proliferating leukaemic $\mathrm{CD} 34^{+}$cells. $\mathrm{Br}$. $J$. Haematol. 118: 521-534.

Krause, D.S., Fackler, M.J., Civin, C.I., and May, W.S. 1996. CD34: Structure, biology, and clinical utility. Blood 87: 1-13.

Kroon, E., Krosl, J., Thorsteinsdottir, U., Baban, S., Buchberg, A.M., and Sauvageau, G. 1998. Hoxa9 transforms primary bone marrow cells through specific collaboration with Meis Ia but not Pbx1b. EMBO J. 17: 3714-3725.

Lagasse, E. and Weissman, I.L. 1992. Mouse MRP8 and MRP14, two intracellular calcium-binding proteins associated with the development of the myeloid lineage. Blood 79: 1907-1915.

Lapidot, T., Sirard, C., Vormoor, J., Murdoch, B., Hoang, T., Caceres-Cortes, J., Minden, M., Paterson, B., Caligiuri, M.A., and Dick, J.E. 1994. A cell initiating human acute myeloid leukaemia after transplantation into SCID mice. Nature 367: 645-648.

Larochelle, A., Vormoor, J., Hanenberg, H., Wang, J.C., Bhatia, M., Lapidot, T., Moritz, T., Murdoch, B., Xiao, X.L., Kato, I., Williams, D.A., and Dick, J.E. 1996. Identification of primitive human hematopoietic cells capable of repopulating NOD/SCID mouse bone marrow: Implications for gene therapy. Nat. Med. 2: 1329-1337.

Lavau, C., Luo, R.T., Du, C., and Thirman, M.J. 2000. Retrovirus-mediated gene transfer of MLL-ELL transforms primary myeloid progenitors and causes acute myeloid leukemias in mice. Proc. Natl. Acad. Sci. 97: 10984-10989.

Lessard, J. and Sauvageau, G. 2003. Bmi-1 determines the proliferative capacity of normal and leukaemic stem cells. Nature 423: 255-260.

Majeti, R., Park, C., and Weissman, I. 2007. Identification of a hierarchy of multipotent hematopoietic progenitors in human cord blood. Cell Stem Cell 1: 635-645.

Manz, M.G., Miyamoto, T., Akashi, K., and Weissman, I.L. 2002. Prospective isolation of human clonogenic common myeloid progenitors. Proc. Natl. Acad. Sci. 99: 11872-11877.

Mazurier, F., Gan, O.I., McKenzie, J.L., Doedens, M., and Dick, J.E. 2004. Lentivector-mediated clonal tracking reveals intrinsic heterogeneity in the human hematopoietic stem cell compartment and culture-induced stem cell impairment. Blood 103: 545-552.

McKenzie, J.L., Gan, O.I., Doedens, M., Wang, J.C., and Dick, J.E. 2006. Individual stem cells with highly variable proliferation and self-renewal properties comprise the human hematopoietic stem cell compartment. Nat. Immunol. 7: 1225-1233.

Michallet, M., Philip, T., Philip, I., Godinot, H., Sebban, C., Salles, G., Thiebaut, A., Biron, P., Lopez, F., Mazars, P., et al. 2000. Transplantation with selected autologous peripheral blood CD $34^{+}$Thy $1^{+}$hematopoietic stem cells (HSCs) in multiple myeloma: Impact of HSC dose on engraftment, safety, and immune reconstitution. Exp. Hematol. 28: 858-870.

Miller, J.S., McCullar, V., Punzel, M., Lemischka, I.R., and Moore, K.A. 1999. Single adult human CD34 $/ \mathrm{Lin}^{-} / \mathrm{CD} 38^{-}$ progenitors give rise to natural killer cells, B-lineage cells, dendritic cells, and myeloid cells. Blood 93: 96-106.

Miyamoto, T., Weissman, I.L., and Akashi, K. 2000. AML1/ETO-expressing nonleukemic stem cells in acute myelogenous leukemia with 8;21 chromosomal translocation. Proc. Natl. Acad. Sci. 97: 7521-7526.

Mohle, R., Bautz, F., Rafii, S., Moore, M.A., Brugger, W., and Kanz, L. 1998. The chemokine receptor CXCR-4 is expressed on $\mathrm{CD} 34^{+}$hematopoietic progenitors and leukemic cells and mediates transendothelial migration induced by stromal cellderived factor-1. Blood 91: 4523-4530.

Morrison, S.J. and Weissman, I.L. 1994. The long-term repopulating subset of hematopoietic stem cells is deterministic and isolatable by phenotype. Immunity 1: 661-673.

Morrison, S.J., Prowse, K.R., Ho, P., and Weissman, I.L. 1996. Telomerase activity in hematopoietic cells is associated with self-renewal potential. Immunity 5: 207-216.

Morrison, S.J., Wandycz, A.M., Hemmati, H.D., Wright, D.E., and Weissman, I.L. 1997. Identification of a lineage of multipotent hematopoietic progenitors. Development 124: 1929-1939.

Nagasawa, T., Hirota, S., Tachibana, K., Takakura, N., Nishikawa, S., Kitamura, Y., Yoshida, N., Kikutani, H., and Kishimoto, T. 1996. Defects of B-cell lymphopoiesis and bone-marrow myelopoiesis in mice lacking the $\mathrm{CXC}$ chemokine PBSF/SDF-1. Nature 382: 635-638.

Negrin, R.S., Atkinson, K., Leemhuis, T., Hanania, E., Juttner, C., Tierney, K., Hu, W.W., Johnston, L.J., Shizurn, J.A., Stockerl-Goldstein, K.E., et al. 2000. Transplantation of highly purified CD $34^{+}$Thy- $1^{+}$hematopoietic stem cells in patients with metastatic breast cancer. Biol. Blood Marrow Transplant. 6: 262-271.

Notaro, R., Cimmino, A., Tabarini, D., Rotoli, B., and Luzzatto, L. 1997. In vivo telomere dynamics of human hematopoietic stem cells. Proc. Natl. Acad. Sci. 94: 13782-13785.

Ogawa, M. 1993. Differentiation and proliferation of hematopoietic stem cells. Blood 81: 2844-2853.

Osawa, M., Hanada, K., Hamada, H., and Nakauchi, H. 1996. Long-term lymphohematopoietic reconstitution by a single CD34-low/negative hematopoietic stem cell. Science 273: 242-245.

Papayannopoulou, T., Craddock, C., Nakamoto, B., Priestley, G.V., and Wolf, N.S. 1995. The VLA4/VCAM-1 adhesion pathway defines contrasting mechanisms of lodgement of transplanted murine hemopoietic progenitors between bone marrow and spleen. Proc. Natl. Acad. Sci. 92: 9647-9651.

Passegué, E., Wagner, E.F., and Weissman, I.L. 2004. JunB defi- 
ciency leads to a myeloproliferative disorder arising from hematopoietic stem cells. Cell 119: 431-443.

Peled, A., Petit, I., Kollet, O., Magid, M., Ponomaryov, T., Byk, T., Nagler, A., Ben-Hur, H., Many, A., Shultz, L., et al. 1999. Dependence of human stem cell engraftment and repopulation of NOD/SCID mice on CXCR4. Science 283: 845-848.

Peled, A., Kollet, O., Ponomaryov, T., Petit, I., Franitza, S., Grabovsky, V., Slav, M.M., Nagler, A., Lider, O., Alon, R., Zipori, D., and Lapidot, T. 2000. The chemokine SDF-1 activates the integrins LFA-1, VLA-4, and VLA-5 on immature human $\mathrm{CD}_{3}{ }^{+}$cells: Role in transendothelial/stromal migration and engraftment of NOD/SCID mice. Blood 95: 3289-3296.

Petzer, A.L., Hogge, D.E., Landsdorp, P.M., Reid, D.S., and Eaves, C.J. 1996. Self-renewal of primitive human hematopoietic cells (long-term-culture-initiating cells) in vitro and their expansion in defined medium. Proc. Natl. Acad. Sci. 93: $1470-1474$.

Potocnik, A.J., Brakebusch, C., and Fassler, R. 2000. Fetal and adult hematopoietic stem cells require $\beta 1$ integrin function for colonizing fetal liver, spleen, and bone marrow. Immunity 12: 653-663.

Raaphorst, F.M. 2003. Self-renewal of hematopoietic and leukemic stem cells: A central role for the Polycomb-group gene Bmi-1. Trends Immunol. 24: 522-524.

Reya, T., Duncan, A.W., Ailles, L., Domen, J., Scherer, D.C., Willert, K., Hintz, L., Nusse, R., and Weissman, I.L. 2003. A role for Wnt signalling in self-renewal of haematopoietic stem cells. Nature 423: 409-414.

Robertson, M.J., Manley, T.J., Pichert, G., Cameron, C., Cochran, K.J., Levine, H., and Ritz, J. 1995. Functional consequences of APO-1/Fas (CD95) antigen expression by normal and neoplastic hematopoietic cells. Leuk. Lymphoma 17: $51-61$.

Sauvageau, G., Thorsteinsdottir, U., Eaves, C.J., Lawrence, H.J., Largman, C., Lansdorp, P.M., and Humphries, R.K. 1995. Overexpression of $H O X B 4$ in hematopoietic cells causes the selective expansion of more primitive populations in vitro and in vivo. Genes Dev. 9: 1753-1765.

Siminovitch, L., McCulloch, E.A., and Till, J.E. 1963. The distribution of colony-forming cells among spleen colonies. $J$. Cell. Physiol. 62: 327-336.

Smith, L.G., Weissman, I.L., and Heimfeld, S. 1991. Clonal analysis of hematopoietic stem-cell differentiation in vivo. Proc. Natl. Acad. Sci. 88: 2788-2792.

So, C.W., Karsunky, H., Passegué, E., Cozzio, A., Weissman, I.L., and Cleary, M.L. 2003. MLL-GAS7 transforms multipotent hematopoietic progenitors and induces mixed lineage leukemias in mice. Cancer Cell 3: 161-171.

Spangrude, G.J., Heimfeld, S., and Weissman, I.L. 1988. Purification and characterization of mouse hematopoietic stem cells. Science 241: 58-62.

Thorsteinsdottir, U., Sauvageau, G., and Humphries, R.K. 1999. Enhanced in vivo regenerative potential of HOXB4-transduced hematopoietic stem cells with regulation of their pool size. Blood 94: 2605-2612.
Thorsteinsdottir, U., Mamo, A., Kroon, E., Jerome, L., Bijl, J., Lawrence, H.J., Humphries, K., and Sauvageau, G. 2002. Overexpression of the myeloid leukemia-associated Hoxa9 gene in bone marrow cells induces stem cell expansion. Blood 99: $121-129$.

Till, J.E. and McCulloch, C.E. 1961. A direct measurement of the radiation sensitivity of normal mouse bone marrow cells. Radiat. Res. 14: 213-222.

Traver, D., Akashi, K., Weissman, I.L., and Lagasse, E. 1998. Mice defective in two apoptosis pathways in the myeloid lineage develop acute myeloblastic leukemia. Immunity 9: $47-57$.

Uchida, N. and Weissman, I.L. 1992. Searching for hematopoietic stem cells: Evidence that Thy- $1.1^{\text {lo }} \mathrm{Lin}^{-} \mathrm{Sca}-1^{+}$cells are the only stem cells in C57BL/Ka-Thy-1.1 bone marrow. $J$. Exp. Med. 175: 175-184.

Varnum-Finney, B., Xu, L., Brashem-Stein, C., Nourigat, C., Flowers, D., Bakkour, S., Pear, W.S., and Bernstein, I.D. 2000. Pluripotent, cytokine-dependent, hematopoietic stem cells are immortalized by constitutive Notch1 signaling. Nat. Med. 6: $1278-1281$.

Vose, J.M., Bierman, P.J., Lynch, J.C., Atkinson, K., Juttner, C., Hanania, C.E., Bociek, G., and Armitage, J.O. 2001. Transplantation of highly purified CD $34^{+} \mathrm{Thy}-1^{+}$hematopoietic stem cells in patients with recurrent indolent nonHodgkin's lymphoma. Biol. Blood Marrow Transplant. 7: 680-687.

Wagers, A.J., Allsopp, R.C., and Weissman, I.L. 2002a. Changes in integrin expression are associated with altered homing properties of Lin ${ }^{-/ \mathrm{lo}} \mathrm{Thy} 1.1^{\mathrm{lo}} \mathrm{Sca}-1^{+} \mathrm{c}-\mathrm{kit}^{+}$hematopoietic stem cells following mobilization by cyclophosphamide/granulocyte colony-stimulating factor. Exp. Hematol. 30: 176-185.

Wagers, A.J., Sherwood, R.I., Christensen, J.L., and Weissman, I.L. 2002b. Little evidence for developmental plasticity of adult hematopoietic stem cells. Science 297: 2256-2259.

Wright, D.E., Bowman, E.P., Wagers, A.J., Butcher, E.C., and Weissman, I.L. 2002. Hematopoietic stem cells are uniquely selective in their migratory response to chemokines. J. Exp. Med. 195: 1145-1154.

Wright, D.E., Wagers, A.J., Gulati, A.P., Johnson, F.L., and Weissman, I.L. 2001. Physiological migration of hematopoietic stem and progenitor cells. Science 294: 1933-1936.

Wu, A.M., Till, J.E., Siminovitch, L., and McCulloch, E.A. 1968. Cytological evidence for a relationship between normal hemotopoietic colony-forming cells and cells of the lymphoid system. J. Exp. Med. 127: 455-464.

Yuan, Y., Zhou, L., Miyamoto, T., Iwasaki, H., Harakawa, N., Hetherington, C.J., Burel, S.A., Lagasse E., Weissman, I.L., Akashi, K., and Zhang, D.E. 2001. AML1-ETO expression is directly involved in the development of acute myeloid leukemia in the presence of additional mutations. Proc. Natl. Acad. Sci. 98: 10398-10403.

Zou, Y.R., Kottmann, A.H., Kuroda, M., Taniuchi, I., and Littman, D.R. 1998. Function of the chemokine receptor CXCR4 in haematopoiesis and in cerebellar development. Nature 393: 595-599. 


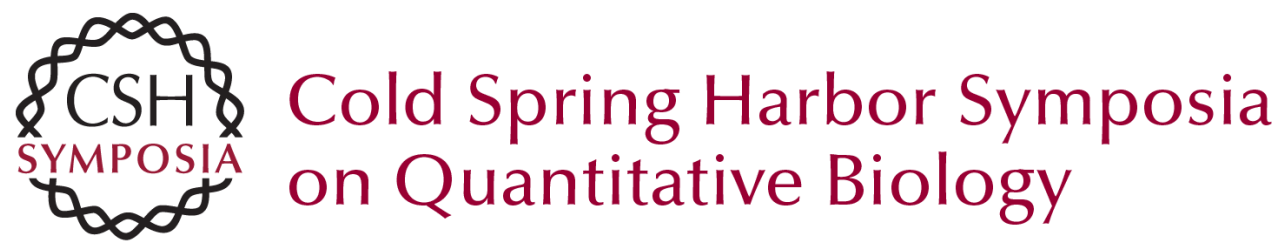

\section{Establishment of a Normal Hematopoietic and Leukemia Stem Cell Hierarchy}

M.P. Chao, J. Seita and I.L. Weissman

Cold Spring Harb Symp Quant Biol 2008 73: 439-449 originally published online November 6, 2008 Access the most recent version at doi:10.1101/sqb.2008.73.031

References This article cites 104 articles, 55 of which can be accessed free at: http://symposium.cshlp.org/content/73/439.full.html\#ref-list-1

\section{License}

Email Alerting Receive free email alerts when new articles cite this article - sign up in the box at the Service top right corner of the article or click here. 